\title{
High Performance Concrete using Industrial by Products
}

\author{
Thendral. S, Arunya A, R. Chitra
}

\begin{abstract}
The papers displayed to think about the trademark quality of superior solid utilizing lime powder, fly debris, and quarry dust with ideal utilization of concrete. To discover the immersion Point of greatest quality and other potential parameters broad work is arranged in this work. The ideal degree of $20 \%$ fly debris, $5 \%$ lime powder and $20 \%$ quarry dust was included with the whole example. The information was gathered from the comparative sort of work did from the past looks into. The evaluation of cement utilized for this work was M30, lime powder and fly debris was supplanted with bond by volume of 5\% and $20 \%$, and the quarry dust was supplanted with sand by volume of 20\%. Absolutely of 3D squares 102 of size $150 \times 150 \times 150 \mathrm{~mm}$ and 12 chambers of size $150 \mathrm{mmx} 300 \mathrm{~mm}$ were thrown for this examination. It was proposed to contemplate the compressive quality, spilt rigidity for every one of the examples with various mixes. The toughness test, for example, salt water obstruction, corrosive opposition, sulfate obstruction and water ingestion was directed. The non dangerous test, for example, bounce back mallet test and Ultrasonic heartbeat speed test were directed before inundation and after drenching examples.
\end{abstract}

Keywords - Lime powder, Fly ash, Quarry dust, durability, High performance Concrete

\section{INTRODUCTION}

Elite concrete is utilized for solid blend which forces high usefulness, high quality, high modules of versatility, high thickness, high dimensional security, low porousness and protection from concoction assault[1]-[4]. It might be reviewed that in typical cement, generally low quality and versatile modules are the consequence of high heterogeneous nature of structure of the material. A considerable decrease of amount of blending water is the major advance for making elite concrete. Decrease of water bond proportion will bring about high quality cement however decrease in water concrete proportion to under 0.3 will incredibly improve the characteristics of progress zone. It gives characteristic characteristics expected in superior cement. Receiving water concrete proportion in the range 0.25 to 0.3 and getting a high droop is conceivable just with the utilization of super plasticizer. In this manner the utilization of suitable super plasticizer is a key material in making High execution concrete the related issue is the choice of super plasticizer

Revised Manuscript Received on October 22, 2019.

Thendral. S, Department of Civil Engineering, Bharath Institute of Higher Education and Research, Chennai , India. Email: thendral.cs@gmail.com

Arunya A, Department of Civil Engineering, Bharath Institute of Higher Education and Research, Chennai , India. Email: arunyaaaa@gmail.com

R. Chitra , Department of Civil Engineering, Bharath Institute of Higher Education and Research, Chennai , India. Email: chitraroopauma@gmail.com and that of bond so they are perfect and hold the droop and the sensible properties for an adequately prolonged stretch of time till concrete undeniably put and compacted[5]-[8].

\section{A. Objectives}

The crude materials utilized for this investigation are common coarse total, fine amassed, and 43 evaluations Portland concrete, the size of the coarse total of the greatest size $20 \mathrm{~mm}$ and fineness Modulus (FM) of 7.18 was utilized, and furthermore the particular gravity was seen as 2.57 , fine total was characteristic waterway sand affirming to Zone II of IS 383:1970 with most extreme size of under 4.75 the particular gravity was seen as 2.57 , and the particular gravity of fly debris 2.74 ,the fly was gotten from the neyveli warm power station. A great lime powder for the most part allows a decrease in substance of solid blends, without loss of functionality[9]-[14]. The particular gravity of lime powder 2.72. The quarry dust with sand substitution, it is the national modern results material.The particular gravity of quarry dust 2.683. What's more, the fineness modulus of quarry dust 3.032 , it was gotten from the quarry and lime powder to approach chidambaram.

\section{MATERIALS AND METHODS}

\section{A.Materials and Mix Proportion}

The crude materials utilized for this investigation are common coarse total, fine amassed, and 43 evaluations Portland concrete, the size of the coarse total of the greatest size $20 \mathrm{~mm}$ and fineness Modulus (FM) of 7.18 was utilized, and furthermore the particular gravity was seen as 2.57 , fine total was characteristic waterway sand affirming to Zone II of IS 383:1970 with most extreme size of under 4.75 the particular gravity was seen as 2.57 , and the particular gravity of fly debris 2.74 ,the fly was gotten from the neyveli warm power station[15]-[20]. A great lime powder for the most part allows a decrease in substance of solid blends, without loss of functionality. The particular gravity of lime powder 2.72. The quarry dust with sand substitution, it is the national modern results material .The particular gravity of quarry dust 2.683. What's more, the fineness modulus of quarry dust 3.032, it was gotten from the quarry and lime powder to approach chidambaram. 
Table - 1 Mix Proportions

\begin{tabular}{|c|c|c|c|}
\hline Water & Cement \\
$\mathbf{m}^{3}$ & $\mathbf{k g} / \mathbf{m}^{3}$ & $\begin{array}{c}\text { Fine aggregate } \\
\mathbf{k g} / \mathbf{m}^{3}\end{array}$ & $\begin{array}{c}\text { Coarse aggregate } \\
\mathbf{k g} / \mathbf{m}^{3}\end{array}$ \\
\hline 191.6 & 383 & 573 & 1239 \\
\hline 0.50 & 1 & 1.5 & 3.25 \\
\hline
\end{tabular}

\section{B . Methodology}

The Selection of materials dependent on the properties ought to be tried before beginning the work[21]-[24]. Visual from blend configuration is proposed to be embraced, for example, a reality the mix on bond that can be trademark quality a blend proportioning to be finished by ordinary preliminary blending approaches for, wanted droop esteem, to contemplating the attributes of elite concrete by directing compressive quality and spit tractable test and furthermore concentrating the toughness test, for example, water retention, corrosive obstruction and salt water opposition and sulfate opposition test, concentrating the non-ruinous test, for example, bounce back hammer test and ultrasonic beat speed test before drenching and after submersion examples, to analyze the outcome for both traditional concrete and superior.

\section{Test Methods}

The trial study embraced to research the impact of halfway supplanting of sand with quarry dust, bond with fly debris and lime powder, on the solid compressive quality advancement. Two kinds of supplanting extent of sand with quarry dust 5 to $20 \%$ and bond with fly debris $20 \%$ and lime powder 5 to 20 $\%$ were rehearsed in the solid blends aside from in the conversional solid blend, the test was performed on 3D square examples of 150x150x150 mm, Cured in water for 7 th days, under controlled research facility whole study, the compressive quality of the water relieved examples were estimated on the 7 days quality[25]-[29].

In our exploratory we have utilize the diverse level of quarry dust with sand substitution in, for example, among that rate the $20 \%$ of quarry dust invigorated the great compressive and distinctive level of lime powder with concrete substitution in, for example, among that rate the $5 \%$ of lime powder and $20 \%$ of fly debris is the great compressive quality. The preliminary blending subtleties show the underneath table

The readied solid examples were restored in water during 28 th days. And afterward the examples were expelled from the relieving tank and dried in room condition to decide the compressive quality and the split elasticity. Each solid clusters 6 3D square examples having 150x150x150 mm measurements were tried under for compressive quality and 8 shapes example were tried under split rigidity, Modulus of Elasticity This was controlled by running a heap diversion estimation on $150 \mathrm{~mm}$ breadth and length $300 \mathrm{~mm}$ [30]-[32]

\begin{tabular}{|c|c|c|c|}
\hline S.NO & Name Of Test & Types of concrete & $\begin{array}{l}\text { Numbers of } \\
\text { specimens }\end{array}$ \\
\hline \multirow[t]{2}{*}{1} & \multirow{2}{*}{$\begin{array}{l}\text { Compressive strength } \\
(150 \times 150 \times 150 \mathrm{~mm})\end{array}$} & Conventional concrete & 3 \\
\hline & & $\begin{array}{l}\text { High performance } \\
\text { concrete }\end{array}$ & 3 \\
\hline \multirow[t]{2}{*}{2} & \multirow{2}{*}{$\begin{array}{l}\text { Spilt tensile strength } \\
(150 \times 300 \mathrm{~mm})\end{array}$} & Conventional concrete & 3 \\
\hline & & $\begin{array}{l}\text { High performance } \\
\text { concrete }\end{array}$ & 3 \\
\hline \multirow[t]{2}{*}{4} & \multirow{2}{*}{$\begin{array}{l}\text { Young's Modulus } \\
(150 \times 300 \mathrm{~mm})\end{array}$} & Conventional concrete & 3 \\
\hline & & $\begin{array}{l}\text { High performance } \\
\text { concrete }\end{array}$ & 3 \\
\hline \multirow[t]{2}{*}{5} & \multirow[b]{2}{*}{$\begin{array}{c}\text { Durability study } \\
(150 \times 150 \times 150 \mathrm{~mm})\end{array}$} & Conventional concrete & 48 \\
\hline & & $\begin{array}{l}\text { High performance } \\
\text { concrete }\end{array}$ & 48 \\
\hline \multicolumn{3}{|c|}{ Total numbers of specimens } & 66 \\
\hline
\end{tabular}

\section{RESULTS AND DISCUSSION}

The use of industrial byproducts for concrete in becoming more popular with the introduction of low cost high performance concrete in this project lime powder $5 \%$,fly ash $20 \%$ were used as replacement material for cement and quarry dust $20 \%$ was used as a replacement material for sand and made a high performance concrete (HPC). the strength test such as compressive strength and tensile strength were carried out on concrete cubes and cylinders for conventional concrete $(\mathrm{CC})$ and high performance concrete. The durability study such as were water observation, acid resistances, sulphate resistances, salt resistances test were conducted on both concrete, the non-destructive tests Rebound hammer, Ultrasonic pulse velocity such as also conducted the both concrete[33]-[34]. From the experimental investigation the following finding are demined.

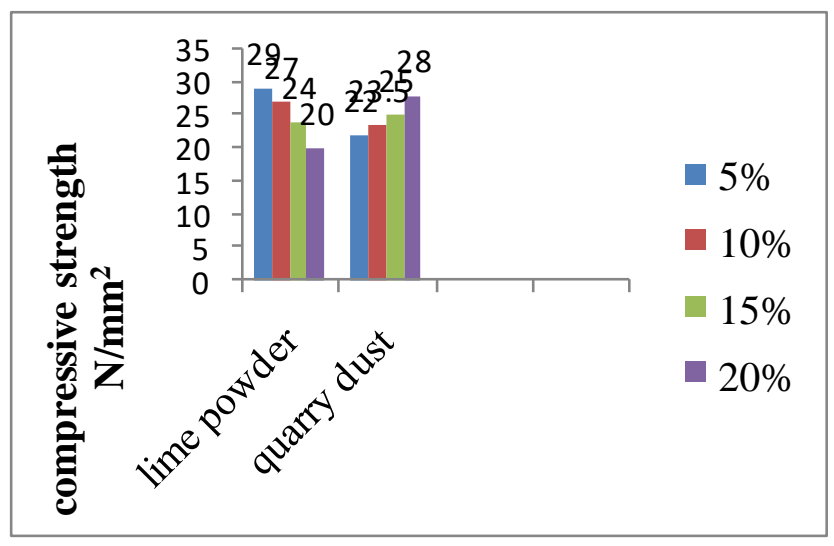

\section{CONCLUSION}

- $\quad$ HPC had higher compressive strength is an average of $41.63 \mathrm{~N} / \mathrm{mm} 2$ at 28 days using which is almost \% higher with respect to $\mathrm{CC}$.

- $\quad$ HPC had higher tensile strength is an average of 3.2 $\mathrm{N} / \mathrm{mm} 2$ at 28 days using which is almost \% higher with respect to $\mathrm{CC}$.

- $\quad$ HPC had higher young's modulus is an average of $41.63 \mathrm{~N} / \mathrm{mm} 2$ at 28 days using which is almost \% higher with respect to $\mathrm{CC}$. 
The water absorption of HPC concrete is 34.33 $\mathrm{N} / \mathrm{mm} 2$ and is less then \% with respect to CC. It is obtained that the compressive strength of HPC concrete is 34.33 $\mathrm{N} / \mathrm{mm} 2$ and is higher \% with respect to $\mathrm{CC}$.

The acid resistances of HPC concrete is $21.7 \mathrm{~N} / \mathrm{mm} 2$ and is less then \% with respect to CC. It is obtained that the compressive strength of HPC concrete is $21.7 \mathrm{~N} / \mathrm{mm} 2$ and is higher $\%$ with respect to $\mathrm{CC}$.

- The sulphate resistances of HPC concrete is 34.33 $\mathrm{N} / \mathrm{mm} 2$ and is less then \% with respect to CC. It is obtained that the compressive strength of HPC concrete is 34.33 $\mathrm{N} / \mathrm{mm} 2$ and is higher \% with respect to $\mathrm{CC}$.

- The salt resistances of HPC concrete is $34.2 \mathrm{~N} / \mathrm{mm} 2$ and is less then \% with respect to CC. It is obtained that the compressive strength of HPC concrete is $34.2 \mathrm{~N} / \mathrm{mm} 2$ and is higher $\%$ with respect to $\mathrm{CC}$.

- Rebound hammer test for water absorption of HPC concrete is 31 , and is less than 24.3 with respect to CC.

Rebound hammer test for acid resistances of HPC concrete is 27.2 , and is less than 22.3 with respect to CC.

- Rebound hammer test for sulphate resistances of HPC concrete is 24.8 , and is less than 20.4 with respect to CC.

- Rebound hammer test for salt resistances of HPC concrete is 22 , and is less than 21.2 with respect to $\mathrm{CC}$.

UPV test for water absorption of HPC concrete is $4550 \mathrm{~m} / \mathrm{s}$ and is less than $4340 \mathrm{~m} / \mathrm{s}$ with respect to CC.

- UPV test for acid resistances of HPC concrete is $4550 \mathrm{~m} / \mathrm{s}$ and is less than $4380 \mathrm{~m} / \mathrm{s}$ with respect to $\mathrm{CC}$.

- UPV test for sulphate resistances of HPC concrete is $4460 \mathrm{~m} / \mathrm{s}$ and is less than $4380 \mathrm{~m} / \mathrm{s}$ with respect to CC.

- UPV test for salt resistances of HPC concrete is $4440 \mathrm{~m} / \mathrm{s}$ and is less than $4290 \mathrm{~m} / \mathrm{s}$ with respect to CC.

\section{REFERENCES}

1. Iyappan L., Dayakar P., Identification of landslide prone zone for coonoortalukusing spatial technology, International Journal of Applied Engineering Research,V-9,I-22,PP-5724-5732,Y-2014.

2. Kumar J., Sathish Kumar K., Dayakar P.,Effect of microsilica on high strength concrete, International Journal of Applied Engineering Research,V-9,I-22,PP-5427-5432,Y-2014.

3. Dayakar P., Vijay Ruthrapathi G., Prakesh J., Management of bio-medical waste, International Journal of Applied Engineering Research,V-9,I-22,PP-5518-5526,Y-2014.

4. Swaminathan N., Dayakar P., Resource optimization in construction project, International Journal of Applied Engineering Research,V-9,I-22,PP-5546-5551,Y-2014.

5. Venkat Raman K., Dayakar P., Raju K.V.B.,An experimental study on effect of cone diameters in penetration test on sandy soil, International Journal of Civil Engineering and Technology,V-8,I-8,PP-1581-1588,Y-2017.

6. Saritha B., Chockalingam M.P.,Photodradation of malachite green DYE using TIO2/activated carbon composite,International Journal of Civil Engineering and Technology,V-8,I-8,PP-156-163,Y-2017

7. Shendge R.B., Chockalingam M.P., Saritha B., Ambica A.,Swat modelling for sediment yield: A case study of Ujjani reservoir in Maharashtra, India,International Journal of Civil Engineering and Technology,V-9,I-1,PP-245-252,Y-2018

8. Chockalingam M.P., Balamurgan V.,Modernisation of an existing urban road-sector in Chennai, a case study report,International Journal of Civil Engineering and Technology,V-8,I-8,PP-1457-1467,Y-2017

9. Saritha B., Chockalingam M.P.,Adsorption study on removal of basic dye by modified coconut shell adsorbent, International Journal of Civil Engineering and Technology,V-8,I-8,PP-1370-1374,Y-2017
10. Saritha B., Chockalingam M.P.,Adsorptive removal of heavy metal chromium from aqueous medium using modified natural adsorbent,International Journal of Civil Engineering and Technology,V-8,I-8,PP-1382-1387,Y-2017

11. Chockalingam M.P., Palanivelraja S.,Retrospective analysis of a theoretical model used for forecasting future air quality near the north Chennai thermal power plant,International Journal of Civil Engineering and Technology,V-8,I-8,PP-1457-1467,Y-2017

12. Saritha B., Chockalingam M.P.,Photodegradation of methylene blue dye in aqueous medium by $\mathrm{Fe}-\mathrm{AC} / \mathrm{TiO} 2$ Composite,Nature Environment and Pollution Technology,V-17,I-4,PP-1259-1265,Y-2018

13. Shendge R.B., Chockalingam M.P., Kaviya B., Ambica A.,Estimates of potential evapotranspiration rates by three methods in upper Bhima Basin, In Maharashtra, India,International Journal of Civil Engineering and Technology,V-9,I-2,PP-475-480,Y-2018

14. Shendge R.B., Chockalingam M.P.,The soil and water assessment tool for Ujjani Reservoir,International Journal of Mechanical Engineering and Technology,V-9,I-2,PP-354-359,Y-2018

15. Shendge R.B., Chockalingam M.P.,A review on soil and water assessment tool,International Journal of Mechanical Engineering and Technology,V-9,I-2,PP-347-353,Y-2018

16. Sachithanandam P., Meikandaan T.P., Srividya T.,Steel framed multi storey residential building analysis and design,International Journal of Applied Engineering Research,V-9,I-22,PP-5527-5529,Y-2014

17. Meikandaan T.P., Ramachandra Murthy A.,Study of damaged RC beams repaired by bonding of CFRP laminates,International Journal of Civil Engineering and Technology,V-8,I-2,PP-470-486,Y-2017

18. Meikandaan T.P., Ramachandra Murthy A.,Retrofittng of reinforced concrete beams using GFRP overlays,International Journal of Civil Engineering and Technology,V-8,I-2,PP-423-439,Y-2017

19. Meikandaan T.P., Ramachandra Murthy A.,Flexural behaviour of RC beam wrapped with GFRP sheets,International Journal of Civil Engineering and Technology,V-8,I-2,PP-452-469,Y-2017

20. Meikandaan T.P., Murthy A.R.,Experimental study on strengthening of rc beams using glass Fiber,International Journal of Civil Engineering and Technology,V-9,I-11,PP-959-965,Y-2018

21. Meikandaan T.P., Hemapriya M.,Use of glass FRP sheets as external flexural reinforcement in RCC Beam,International Journal of Civil Engineering and Technology,V-8,I-8,PP-1485-1501,Y-2017

22. Saraswathy R., Saritha B.,Planning of integrated satellite township at Thirumazhisai,International Journal of Applied Engineering Research,V-9,I-22,PP-5558-5560,Y-2014

23. Saritha B., Ilayaraja K., Eqyaabal Z., Geo textiles and geo synthetics for soil reinforcement,International Journal of Applied Engineering Research,V-9,I-22,PP-5533-5536,Y-2014

24. Ambica A., Saritha B., Changring G., Singh N B., Rajen M., Salman Md.,Analysis of groundwater quality in and around Tambaram taluk, Kancheepuram district,International Journal of Civil Engineering and Technology,V-8,I-8,PP-1362-1369,Y-2017

25. Arunya A., Sarayu K., Ramachandra Murthy A., Iyer N.R.,Enhancement of durability properties of bioconcrete incorporated with nano silica,International Journal of Civil Engineering and Technology,V-8,I-8,PP-1388-1394,Y-2017

26. Ilayaraja K., Krishnamurthy R.R., Jayaprakash M., Velmurugan P.M., Muthuraj S.,Characterization of the 26 December 2004 tsunami deposits in Andaman Islands (Bay of Bengal, India),Environmental

Sciences, V-66,I-8,PP-2459-2476,Y-2012

27. Ilayaraja K.,Morphometric parameters of micro watershed in Paravanar sub-basin, Cuddalore District,International Journal of Civil Engineering and Technology,V-8,I-8,PP-1444-1449, Y-2017

28. Ilayaraja K., Singh R.K., Rana N., Chauhan R., Sutradhar N.,Site suitability assessment for residential areas in south Chennai region using remote sensing and GIS techniques,International Journal of Civil Engineering and Technology,V-8,I-8,PP-1468-1475,Y-2017 
29. Ilayaraja K., Reza W., Kumar V., Paul S., Chowdhary R.,Estimation of land surface temperature of Chennai metropolitan area using Landsat images,International Journal of Civil Engineering and Technology,V-8,I-8,PP-1450-1456,Y-2017

30. Chitra R.,Experimental study on beam using steel fiber and latex,International Journal of Civil Engineering and Technology,V-8,I-8,PP-1395-1403,Y-2017

31. Chitra R.,Analysis of traffic and management at Kovilambakkam intersection,International Journal of Civil Engineering and Technology,V-8,I-8,PP-1433-1443,Y-2017

32. Aswathy M.,Experimental study on light weight foamed concrete,International Journal of Civil Engineering and Technology,V-8,I-8,PP-1404-1412,Y-2017

33. Aswathy M.,Wastewater treatment using constructed wetland with water lettuce (Eichornia Crasipies),International Journal of Civil Engineering and Technology,V-8,I-8,PP-1413-1421,Y-2017

34. Kiruthiga K., Anandh K.S., Gunasekaran K, Assessment of influencing factors on improving effectiveness and productivity of construction engineers, 2015, International Journal of Applied Engineering Research, V - 10,I -17,p -13849-13854.

\section{AUTHORS PROFILE}

Thendral. S, Assistant Professor, Department of Civil Engineering, Bharath Institute of Higher Education and Research, Chennai, India.

Arunya A, Assistant Professor, Department of Civil Engineering, Bharath Institute of Higher Education and Research, Chennai, India

R. Chitra, Assistant Professor, Department of Civil Engineering, Bharath Institute of Higher Education and Research, Chennai, India 